Western North American Naturalist 74(4), (C) 2014, pp. 427-433

\title{
TRIMEROTROPIS ABERASTURII (ORTHOPTERA: ACRIDIDAE: OEDIPODINAE), A NEW SPECIES OF BAND-WINGED GRASSHOPPER FROM NORTH CENTRAL NEVADA
}

\author{
Timothy J. McNary ${ }^{1}$
}

\begin{abstract}
Trimerotropis aberasturii, a new species of band-winged grasshopper, is described from the mountains of north central Nevada. It appears most closely related to T. suffusa and T. verruculata. Trimerotropis aberasturii is distinguished from the other 2 species by a more extensive black hind wing band, features of the male genitalia, and geographic distribution.
\end{abstract}

Resumen.-Se describe una nueva especie de saltamonte de alas con banda, Trimerotropis aberasturii, de las montañas del centro-norte de Nevada. Ésta parece más estrechamente relacionada con T. suffusa y T. verruculata. Trimerotropis aberasturii distingue de las otras 2 especies por una más amplia banda de ala posterior negro, características de los genitales masculinos y distribución geográfica.

The new species described herein is a member of the band-winged grasshopper (Oedipodinae) genus Trimerotropis, a New World genus of more than 52 species (Rentz and Weissman 1980, Eades et al. 2014) that ranges from Canada south to Argentina and Chile. The majority of species occur throughout western North America; 4 species occur in eastern North America and 7 species in South America (Eades et al. 2014), although 6 of those have been referred to as synonyms of one (Husemann et al. 2013). All Trimerotropis species are macropterous. They are strong fliers and produce mate-attraction sounds (crepitation) in flight. Many species have widespread geographic ranges, and one species, $T$. pallidipennis (Burmeister), has been recorded from Canada to southern Mexico (Otte 1984, Husemann et al. 2013, Eades et. al. 2014). However, other species are restricted to specific habitats, such as sand dunes or alkaline playas, and have relatively restricted distributions (Otte 1984). Two species, T. verruculata (Kirby) and T. suffusa Scudder, have enlarged anal veins of the hind wings similar to those in Circotettix (Otte 1984). Because of these enlarged veins and the loud sound production (crepitation) during flight, these 2 species have, in the past, been included in Circotettix (Rehn 1904). Trimerotropis suffusa is treated as a subspecies of $T$. verruculata by
Otte (1984) and Eades et. al. (2014) but is recognized as distinct taxon by Vickery (1985), Rentz and Weissman (1980), Weissman and Rentz (1980), and Helwig (1955) based on "ecology, behavior and cytology." The new species described here appears to be most closely related to T. suffusa.

Within the mountain ranges of Nevada, there are 2 previously described endemic species of grasshopper. The White Mountains are home to the endemic spur-throated grasshopper (Melanoplinae) Agnostokasia sublima Gurney and Rentz (1964), and the Spring Mountains of southern Nevada are home to an endemic oedipodine grasshopper, C. crotalum Rehn (Otte 1984). However, the majority of the mountain ranges of Nevada have not been systematically surveyed for grasshoppers. La Rivers (1948), in his "A Synopsis on the Nevada Orthoptera," mentions that "only Charleston Peak [3630 m elevation, in the Spring Mountains] has been semi-adequately worked, the remainder awaiting the necessary field work." Barnum (1964) inventoried the Orthoptera of the Nevada Test Site in southern Nevada but did not include the mountains of central Nevada. Little work has been completed on the Orthoptera of central Nevada since these studies. The names of the mountains and ranges used here follow McLane (1978).

1'USDA-APHIS-PPQ, 2150 Centre Ave., Bldg. B3 E10, Fort Collins, CO 80626. E-mail: cicadabiblio@aol.com 


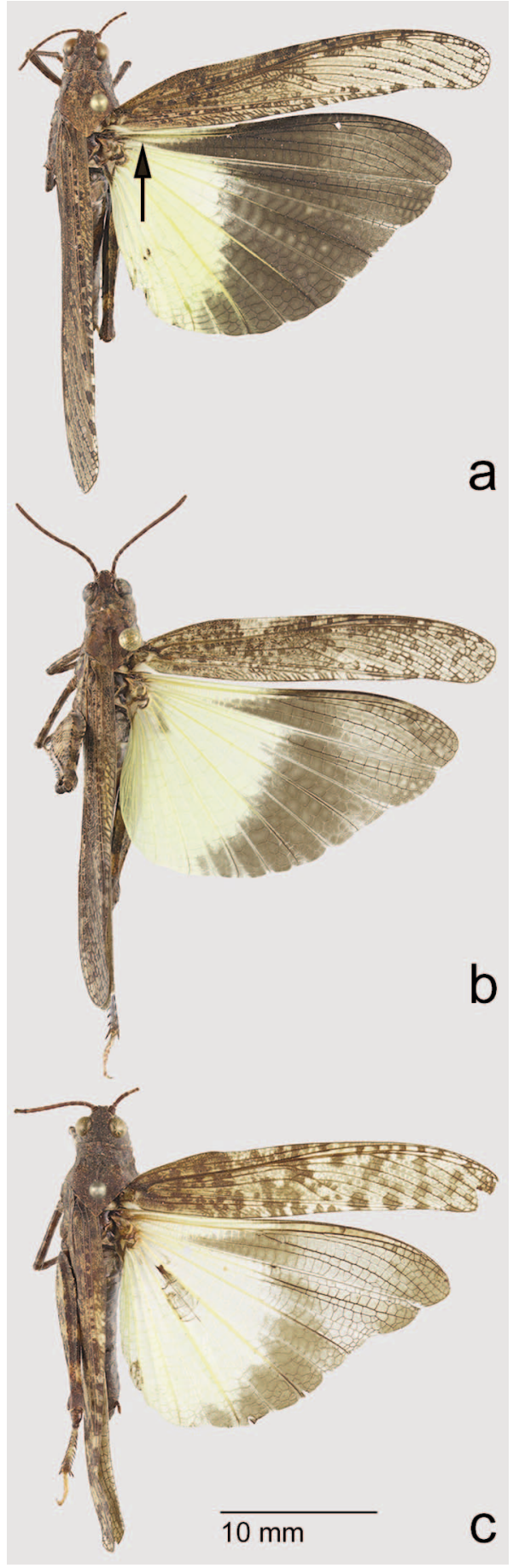

Fig. 1. Photographs showing dorsal views of 3 related species of Trimerotropis: a, holotype male, T. aberasturii; b, T. suffusa, El Dorado County, California; c, T. verruculata, Long Lake, New York.

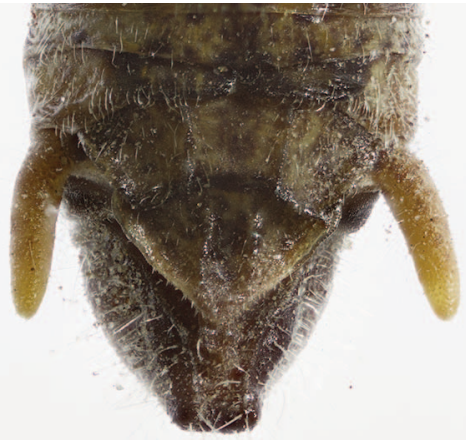

a

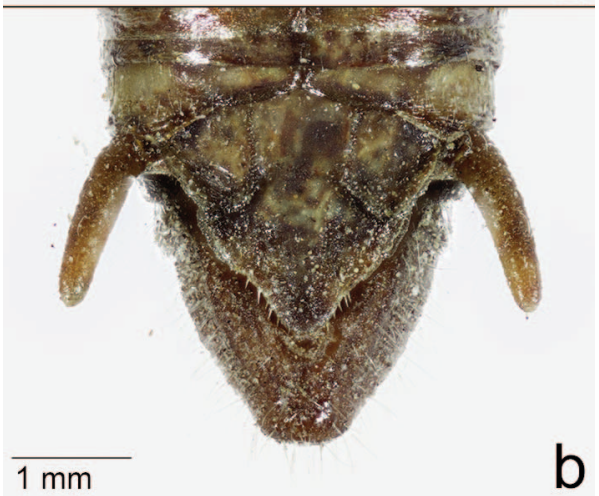

Fig. 2. Photographs showing dorsal view of apex of male subgenital plate: a, holotype, Trimerotropis aberasturii; b, Trimerotropis suffusa. Trinity/Shasta Co., California.

\section{Species Description}

Family Acrididae MacLeay, 1821

Subfamily Oedipodinae Walker, 1871

Genus Trimerotropis Stål, 1873

\section{Trimerotropis aberasturii, new species}

Figs. 1a, 2a, 3

Holotype.-Male, USA, Nevada, Nye County, (Toiyabe Range), N 38 54'00", W $117^{\circ} 22^{\prime} 36^{\prime \prime}, 24-\mathrm{VIII}-2013$, in aspens and pines, 2628 m elevation, T.J. McNary, specimen 13184 (Figs. 1a, 2a). Deposited in the collection of the Academy of Natural Sciences of Drexel University (ANSP).

ParatyPEs.-1 male, 3 females from holotype location, specimens 13185, 13186, 13187, and 13188. Deposited at ANSP. 1 male, 1 female, USA, Nevada, Elko County, (Lamoille Canyon, Ruby Mountains), N 40 $35^{\prime} 45^{\prime \prime}, \mathrm{W}$ $115^{\circ} 22^{\prime} 41^{\prime \prime}, 12-I X-2012$, Subalpine meadow, 2926 m elevation, collector T.J. McNary, specimens 12833 and 12884. 1 female, USA, Nevada, Lander County, Carroll Summit [Desatoya 


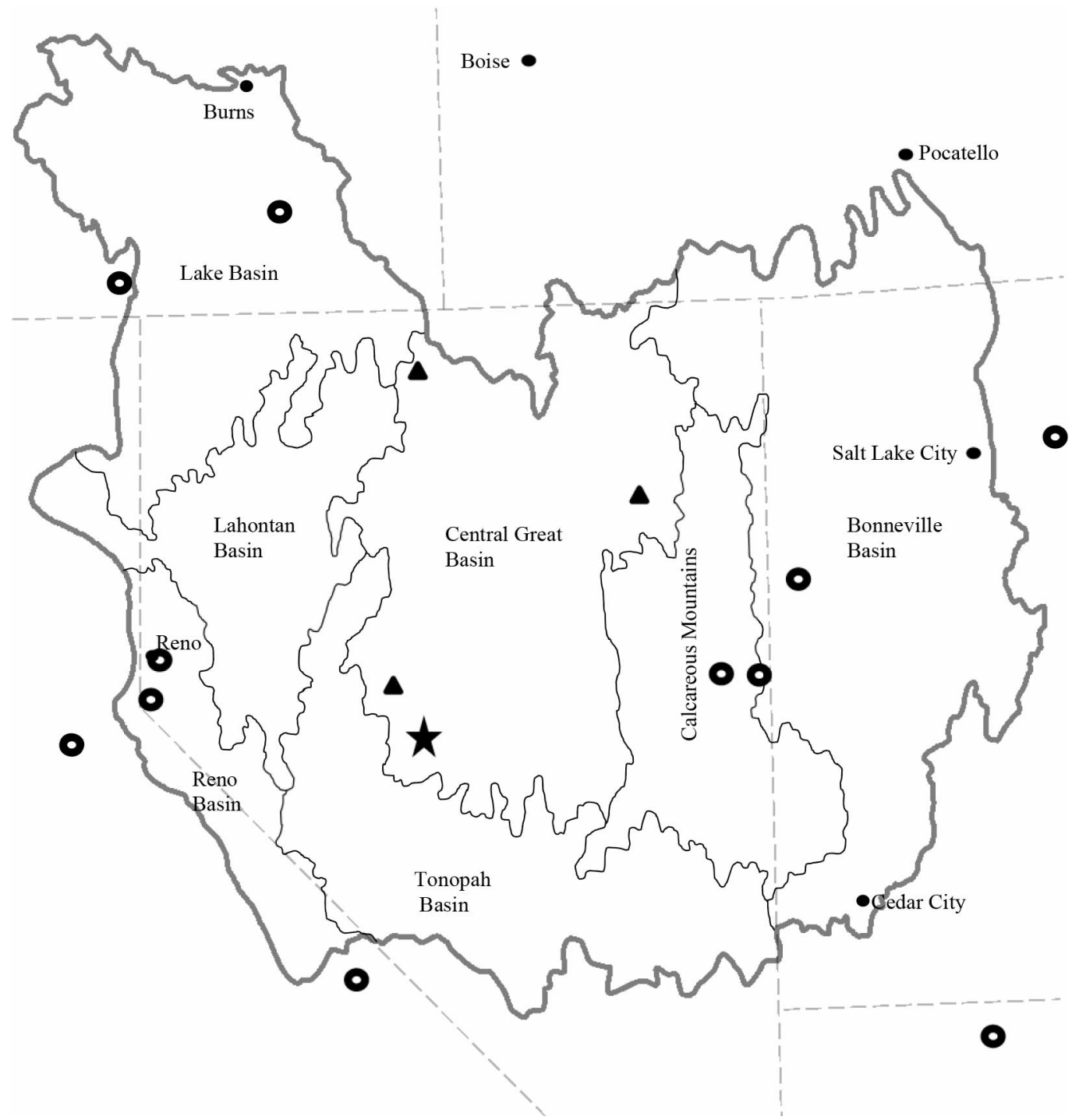

Fig. 3. Trimerotropis aberasturii holotype location $(\star)$ and paratype locations $(\mathbf{\Lambda})$. Trimerotropis suffusa locations surrounding the Great Basin $(\mathbf{0})$.

Range], Highway 722, junipers, 2292 m elevation, 2-VIII-1998, collector T.J. McNary, specimen 4411. Deposited at C.P. Gillette Museum of Arthropod Diversity, Colorado State University (CSUC). 6 males, USA, Nevada, Humboldt County, Santa Rosa Range, Granite Peak, 26-28 July 1979, collector D.C. Lightfoot. Deposited at University of New Mexico, Museum of Southwestern Biology (MSB).

Diagnosis.-The new species is most similar to T. suffusa. The black band of the hind wing is wider (covering the central third of wing) than that of both T. suffusa and T. verruculata. The yellow basal area of T. aberasturii is narrower than in T. suffusa and T. verruculata. The black spur continues as a thin line and reaches the base of the hind wing in $T$. aberasturii (Fig. la, arrow). In T. suffusa and T. verruculata, the black spur is separated from the base of the wing by $3-7 \mathrm{~mm}$. (Fig. $1 \mathrm{~b}$, 1c). The apex of the male subgenital plate of T. aberasturii is quadrate to bilobed (Fig. 2a), while the apex of subgenital plate in T. suffusa is rounded to acute (Fig 2b.) 


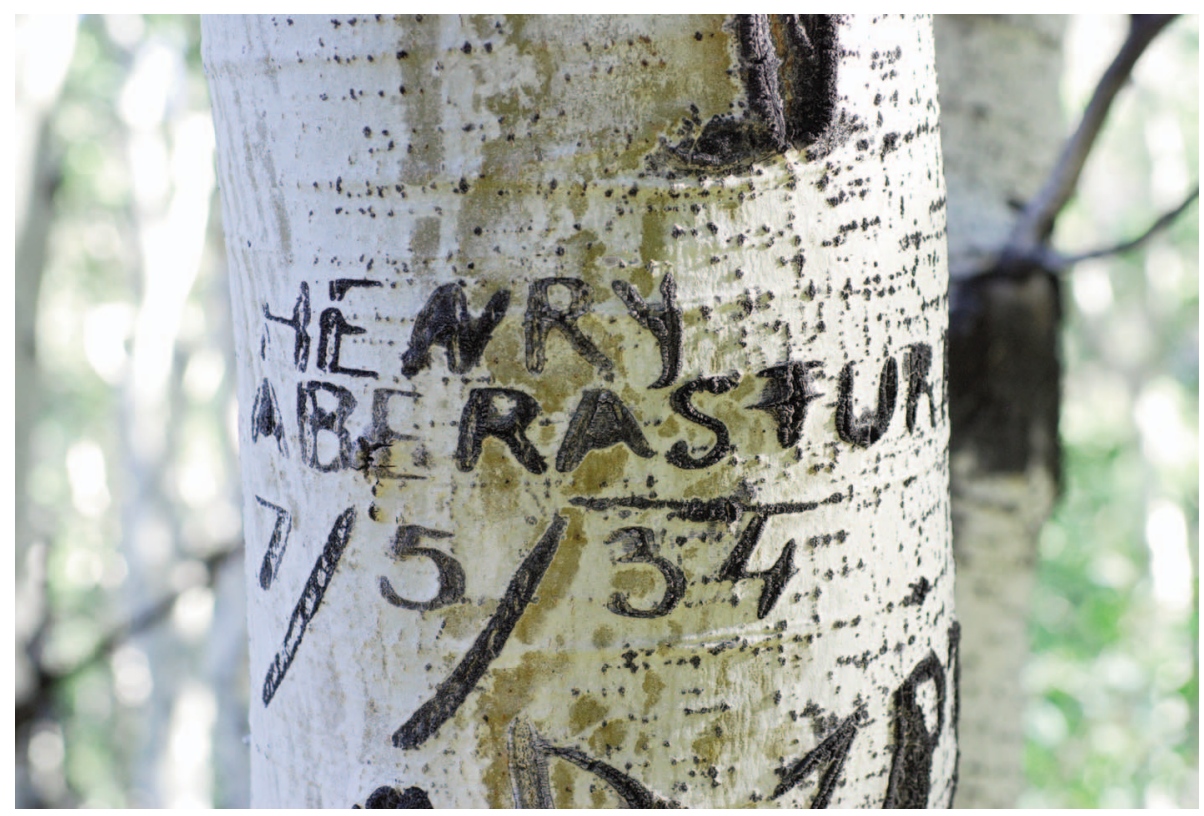

Fig. 4. Henry Aberasturi, a herder who carved his name in this quaking aspen on 5 July 1934 at the holotype location. Aberasturi was one of many immigrant herders who carved their names in the bark of aspens in Nevada mountains.

Etymology.-Named in honor of Henry Aberasturi, a livestock herder who carved his name (Fig. 4) in a quaking aspen tree (Populus tremuloides Michx.) along Stewart's Creek on 5 July 1934 at the type locality (Fig. 5).

DESCRIPTION.-Male length to tip of tegmen $32-35 \mathrm{~mm}(n=8)$, female length $32-38 \mathrm{~mm}$ $(n=5)$. Female and male dark brown. Antenna exhibits faint banding throughout length. Fastigium of head longer than wide, with faint medium ridge, lateral ridge very distinct. Lateral foveolae triangular. Pronotal crest cut twice, posterior cut deep, anterior cut shallow. Posterior angle about $90^{\circ}$. Pronotum with lateral carina incised twice, narrowest at the anterior cut. Lower posterior margin of lateral lobe rounded. Lateral lobe with indistinct darker mark on the mid-anterior edge, rising dorsally to the middle of the pronotal lobe. Fore and mid femora show 3 dark bands separated by slightly lighter bands. Exterior face of hind femur dark brown, with lighter band at the constriction before the knee. Interior face of hind femur black, with white band crossing the constriction before the knee. A second white band is present only on the upper third of the femur, and does not cross the mid or lower areas of the interior face of the femur. Hind tibia brown, darker in distal third, basal white band present, but not distinct. Tegmen dark brown, darkest near the body, no cross bands present but with dark speckles most apparent along the costal and hind margin. Hind wing with broad black central band, distal third nearly as dark or as dark as the central black band. Basal third yellow, divided by the black spur, which reaches the articulation of the wing as a thin line. Proximal junction of the anterior and posterior 2Aa veins located near the edge of the black band and yellow basal area. Anal veins of hind wing swollen. Apex of the male subgenital plate of T. aberasturii is quadrate to bilobed. Female specimen from the Desatoya Range (Carroll Summit) is the largest at $38 \mathrm{~mm}$ to tip of tegmen. Specimens from the Ruby Mountains conform well to the holotype. The specimens from the Santa Rosa Range show more variation in the width of the basal yellow area, ranging from the same as in the holotype to slightly wider. The width of the black band remains wide.

\section{Discussion}

The habitat of T. aberasturii is mixed aspen, limber pine (Pinus flexilis James), and big sagebrush (Artemisia tridentata Nutt.). The known range of elevation is $2300-3050 \mathrm{~m}$. 


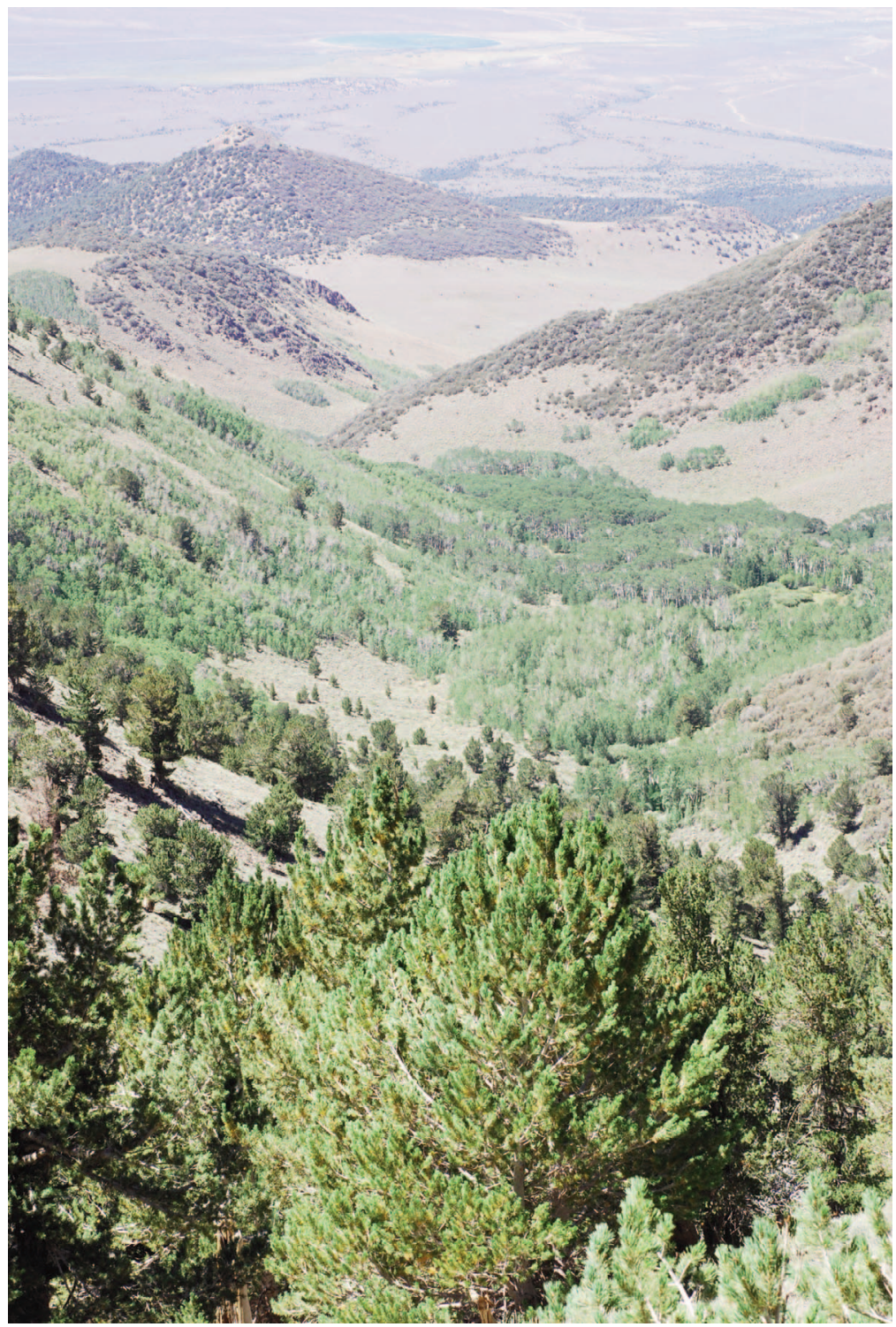

Fig. 5. Looking west down Stewart's Creek in the Toiyabe Range of central Nevada. Holotype locality for Trimerotropis aberasturii is in the central aspen grove.

This species was collected only once from the lower, drier elevations $(2300 \mathrm{~m})$ at Caroll Summit in the Desatoya Range among piñon pine (P. monophylla Torrey and Fremont) and junipers (Juniperus spp.). It has not been collected from the high elevations of dry alpine environments in the Toiyabe Range. The known habitat of T. aberasturii is similar to the habitat of T. suffusa. The crepitation of the new species has not been studied in comparison to that of T. suffusa, but T. aberasturii is similarly loud in flight to T. suffusa and some Circotettix species.

Trimerotropis aberasturii has a known range similar to Holmgren's (1972) Central Great Basin floristic section (Fig. 3). No T. suffusa individuals were collected from this section, whereas T. suffusa was recorded from other Holmgren's Great Basin floristic sections. Specimens of T. suffusa from Holmgren's 
Bonneville and Calcareous Mountains floristic sections (from the Egan, Snake and Schell Creek ranges in eastern Nevada and the Deep Creek Range of far western Utah) are distinct from $T$. aberasturii in showing an acute to rounded subgenital plate in the male, the narrow width of the band, and a spur that does not reach the base of the hind wing. Specimens from the Calcareous Mountains section other than the Egan Range have not been examined, and the separation of T. aberasturii and T. suffusa is unknown in these mountains. The known range of $T$. aberasturii to the northeast is in the Ruby Mountains, southeast of Elko, Nevada, and likely extends into the nearby East Humboldt Range. No specimens were available for study from the Independence and Jarbidge Mountains within the Central Great Basin, and it is unknown where the separation occurs between T. suffusa in southwestern Idaho and T. aberasturii in the Ruby Mountains. Trimerotropis aberasturii apparently reaches its known northern limit in the Santa Rosa Range in northwestern Nevada. Specimens of T. aberasturii from the Santa Rosa Range (on the boundary between the Central Great Basin and the Lake floristic sections) are distinct from specimens of T. suffusa from the Steens Mountains and northern Warner Ranges in adjacent southeastern Oregon in both the band width and spur of the hind wing. Even so, specimens from the Santa Rosa Range may show some integration with T. suffusa, as the yellow area of the hind wing appears to be slightly larger than the yellow area in specimens from the Desatoya Range, Toiyabe Range, or Ruby Mountains. The farthest-west specimen of $T$. aberasturii we studied was from the Desatoya Range. The specimen from the Desatoya Range and those from the Toiyabe Range are distinct from T. suffusa specimens from both the Carson Range northeast of Lake Tahoe and the White Mountains on the California-Nevada border. La Rivers (1948) mentions T. suffusa fallax Saussure 1884 as occurring in Nevada, reporting records from Lander County, Washoe County, and Eureka, Nevada. The identity of the specimens he reported from Eureka would now be uncertain. The Lander and Washoe county records are likely nominate $T$. suffusa, as the nominate $T$. fallax was synonymized with $T$. fontana (Otte 1984). Fifty-five specimens of T. suffusa from California (10), Oregon (12),
Washington (3), Montana (1), Colorado (21), New Mexico (1), Utah (5), and Arizona (2) and 3 specimens of T. verruculata from Maine (2) and New York (1) exhibit no overlap with $T$. aberasturii in either the band width or spur length of the hind wing or in the shape of the male subgenital plate (all specimens housed at CSUC).

\section{ACKNOWLEDGMENTS}

My thanks to Dr. David Lightfoot, University of New Mexico, Museum of Southwestern Biology, for loan of specimens determined as T. aberasturii from Santa Rosa Range, Nevada. Also thanks to Dr. Boris Kondratieff for his reviews of initial drafts and Colorado State University for loans of T. suffusa and T. verruculata specimens from the C.P. Gillette $\mathrm{Mu}-$ seum of Arthropod Diversity. Photographs of holotype T. aberasturii and specimens of $T$. suffusa and T. verruculata were provided by Dr. Todd Gilligan, USDA-APHIS-PPQ, Center for Plant Health Science and Technology, Fort Collins, Colorado.

\section{Literature Cited}

Barnum, A.H. 1964. Orthoptera of the Nevada Test Site. Brigham Young University Science Bulletin, Biological Series 4:1-134.

Eades, D.C., D. Otte, M.M. Cigliano, and H. Braun. 2014. Orthoptera species file, version 5.0/5.0. [Accessed 1 January 2014]. Available from: http://Orthoptera .SpeciesFile.org

Gurney, A.B., And D.C. Rentz. 1964. A new spinethroated grasshopper from the White Mountains of California (Orthoptera: Acrididae: Cyrtacanthacrididae). Proceedings of the California Academy of Sciences 31:504-513.

Helwig, E.R. 1955. Spermatogenesis in hybrids between Circotettix verruculatus and Trimerotropis suffusa (Orthoptera: Oedipodinae). University of Colorado Studies, Series in Biology 3:47-65.

Holmgren, N.H. 1972. Plant geography of the Intermountain Region. Pages 77-161 in A. Cronquist, A.H. Holmgren, N.H. Holmgren, and J.L. Reveal, editors, Intermountain flora: vascular plants of the Intermountain West, U.S.A. Vol. 1. Hafner Publishing Co., New York.

Husemann, M., N.V. Guzman, P.D. Danley, M.M. Cigliano, And V.A. Confalonieri. 2013. Biogeography of Trimerotropis pallidipennis (Acrididae: Oedipodinae): deep divergence across the Americas. Journal of Biogeography 40:261-273.

La Rivers, I. 1948. A synopsis of Nevada Orthoptera. American Midland Naturalist 39:652-720.

MCLANE, A.R. 1978. Silent cordilleras. The mountain ranges of Nevada. Camp Nevada Monographs 4:1-188.

Otте, D. 1984. The North American grasshoppers. Acrididae. Oedipodinae. Volume II. Harvard University Press, Cambridge and London, United Kingdom. 
Rehn, J.A.G. 1904. Notes of Orthoptera from Arizona, New Mexico and Colorado. Proceedings of the Academy of Natural Sciences of Philadelphia 56: $562-575$.

RentZ, D.C.F., And D.B. Weissman. 1980. An annotated checklist of the grasshopper species of Aerochoreutes, Circotettix, and Trimerotropis (Orthoptera: Acrididae: Oedipodinae). Transactions of the American Entomological Society 106:223-252.

VICKERY, V.R. 1985. Note on specific status of Trimerotropis verruculata and T. suffusa (Orthoptera: Acri- didae: Locustinae). Canadian Entomologist 117: 265-266.

Weissman, D.B., and D.C.F. Rentz. 1980. Cytological, morphological, and behavioral characteristics of the trimerotropine (Aerochoreutes, Circotettix, and Trimerotropis) grasshoppers (Orthoptera: Oedipodinae). Transactions of the American Entomological Society 106:253-272.

Received 10 March 2014 Accepted 29 September 2014 